\title{
У пошуках ключа успіху України на світових ринках
}

\begin{abstract}
Проаналізовано позииії Украӥни серед країн СС за показником готовності до майбутнього виробництва (за складовими: складність та структура виробництва, та драйверами: людський капітал та ресурси сталого розвитку) для визначення потенційної конкурентоспроможності Украӥни у процесі інтеграції у таке об'єднання та окреслення можливих шляхів ї̈ підвищення. У дослідженні використано загальнонаукові методи пізнання, зокрема, систематизацію, порівняння, аналіз та синтез. У проиесі дослідження проаналізовано окремі компоненти інтегральної оцінки готовності України до виробництва майбутнього в компаративному аспекті (за складовими: складність та структура виробництва, та драйверами: людський капітал та ресурси сталого розвитку); визначено питання, які потребують першочергового вирішення 3 метою нарощення конкурентних переваг України на світових ринках $i$ спроможності протистояти ризикам та викликам майбутнього; окреслено напрями подальших досліджень. Теоретичне значення дослідження полягає у розвитку (прирості) наукового знання щедо факторів, за якими оиінюється готовність краӥни протистояти ризикам і викликам майбутнього y глобалізованому світі та їх впливу на формування конкурентоспроможності України. Практичне значення отриманих у дослідженні результатів полягає у можливості використання урядом Украӥни, науковою спільнотою та неурядовими організаціями ідентифікованих у дослідженні проблемних точок, за якими існують розриви для розробки стратегії та заходів ії реалізації, яка дасть можливість активізути їх відповідно до значень, рівних або наближених до значень краӥн-членів ЄС. Наукова новизна дослідження полягає у розвитку підходу щодо ідентифікації конкурентних переваг України на світових ринках через компаративний аналіз вибраних показників з країнами СС з огляду на готовність протистояти ризикам та викликам майбутнього.
\end{abstract}

Ключові слова: структура економіки; людські ресурси; інноваційний розвиток; інституційне середовище; міжнародна торгівля.

Актуальність теми. Сучасні динамічні умови глобального економічного середовища вимагають від країн світу бути адаптивними до геоекономічних трансформацій, здатними реагувати на численні загрози та виклики, долучатися до вирішення глобальних проблем. На негативних наслідках глобалізації наголошують Н.В. Стукало та А.О. Сімахова, зауважуючи: «Глобалізація має деякі негативні аспекти, які зумовлюють глобальні проблеми та виклики. Необхідно вказати найбільш значні з них, такі як: глобальні кризи, конфлікти, брак ресурсів, голод, соціальна нерівність, відсутність питної води, емігранти, втрата традицій та культурних особливостей, забруднення навколишнього середовища тощо» [1, с. 36].

Потенціал адаптивності вчені та дослідники вбачають у різних можливостях та ресурсах країн, їхніх стратегіях та інструментах державного управління. Наприклад, для окремих країн на сьогодні стратегічно важливим є володіння енергетичними ресурсами (нині це нафта й газ, проте у найближчій перспективі їх місце займе літій та інші метали, які використовуються для створення засобів живлення), експорт яких забезпечує валютні надходження до країн та зростання валового національного доходу. Це характерно для нафтодобувних країн, які відрізняються надзвичайно високими показниками ВВП на душу населення (порівняно з іншими країнами, що розвиваються), проте значним економічним розшаруванням населення та бідністю.

Для інших країн, які мають територію, незначну за площею, та, відповідно, поклади корисних копалин; були зруйновані війнами або мають тривале колоніальне минуле, запорукою успіху та стрімкого економічного зростання стала структурна перебудова економіки, іiі модернізація, освоєння новітніх технологій та впровадження інновацій (можливо, найкращим прикладом є Японія, де «економічне диво» у 50-х роках XX ст. вивело їі на лідируючі світові позиції, які вона утримує і до сьогодні).

Для країн, які «шукали» себе у світі незалежних держав та позбувалися десятиліттями колоніального статусу, важливою стала побудова дієвої системи державного адміністрування, заснованого, з одного боку, на здобутках та стилі управління, притаманних країні-метрополії (пригадаймо багатовікове панування Великої Британії, Франції, Іспанії та Португалії у Південно-Східній Азії та Латинській Америці), а 3 іншого - на місцевих традиціях та цінностях, які населення плекало у господарстві та побуті, що вносило 
елемент самобутності та оригінального культурно-ментального середовища у функціонування «новоствореної незалежної держави». Прикладами можуть бути Сінгапур та Гонконг.

Тоді в чому ж на сьогодні «рецепт успіху» України, яка ставить собі амбітні плани виходу на світові ринки та повернення у європейський цивілізаційний простір?

За останні роки набуває актуальності системне розуміння засад конкурентоспроможності країни на світових ринках товарів та послуг, іiі привабливості для залучення капіталів, талановитих мігрантів та участі у глобальних виробничих ланцюгах. Тому продовжується дослідження питань комплексної оцінки здатності країни «працювати за правилами» глобалізованого світу, бути успішною серед успішних та забезпечувати власне процвітання за умов досягнення Цілей сталого розвитку. Світовим економічним форумом підготовлено звіт «Готовність до виробництва майбутнього» (Readiness for the Future of Production Report 2018) [5], у якому, відповідно до методології формування показників, визначено драйвери готовності та показники галузевої структури економіки як визначальні для формування адаптивності та конкурентоздатності економіки країни.

Аналіз останніх досліджень та публікацій, на які спираються автори. Інформаційною базою емпіричних даних стали Economic Complexity Rankings (ECI), Environmental Performance Index, Global Gender Gap Index, Human Development Data, ICT Development Index, Readiness for the Future of Production Report, The Logistics Performance Index, The Global Enabling Trade Report, Global Innovation Index, A Global Foreign Direct Investment Country Attractiveness Index.

Теоретичним базисом дослідження з питань глобальних загроз та ризиків стали праці Pliushchyk I.A., Ohorodnyk R.P., Duchynska N.I. (2015) [6], Stukalo N., Simakhova A. (2018) [1], Sardak S., Korneyev M., Simakhova A., Bilskaya O. (2017) [7]. Інституційний аспект розвитку конкурентоспроможної економіки досліджувався на основі праць Ductor L., Grechyna D. (2015) [8], Fouquet R., Broadberry S. (2015) [9]. Праці Greif A., Mokyr J. (2017) [10], Ogilvie S., Carus A.W. (2014) [11], Wanjuu L.Z., le Roux P. (2017) [12] стали основою для теоретичних досліджень проблем трансформації галузевої структури економіки. Питання активізації інноваційної діяльності та ії значення для розвитку економіки досліджувалися за працями Taranenko I.V. (2013) [13, 14], Veugelers R., Schweiger H. (2016) [15], а соціально-демографічні аспекти та розвиток людського потенціалу - за дослідженями Sardak S., Korneyev M., Dzhyndzhoian V. (2018) [16], Teixeira A.A., Queirós A.S. (2016) [17]. Розгляд питань сталого розвитку та екологічної ефективності базувався на працях Bhattacharya M., Paramati S.R., Ozturk I., Bhattacharya S. (2016) [18], Jayaraman R., Lanjouw P.F. (2004) [19].

Метою статті $\epsilon$ аналіз позицій України серед країн $Є С$ за показником готовності до майбутнього виробництва (за складовими: складність та структура виробництва, та драйверами: людський капітал та ресурси сталого розвитку) для визначення потенційної конкурентоспроможності України у процесі інтеграції у вибране об’єднання та окреслення можливих шляхів її підвищення.

Викладення основного матеріалу. В умовах обраного євроінтеграційного вектора геополітичного поступу України сьогодні гостро стоїть питання вибору стратегії подальшого розвитку країни та іiі позиціонування на європейських ринках товарів і послуг. Можливими сценаріями розвитку подій є:

- залишатися сировинним придатком 3 диспропорціями у розвитку галузей економіки та нерозвиненими інститутами, не створюючи конкуренції країнам-членам ЄС й не стати цікавим стратегічним партнером для країн-членів $€ C$;

- вийти на ринок ЄС як повноцінний партнер, що можливо досягти через мінімізацію існуючих диспропорцій у розвитку секторів економіки з урахуванням інституційного та економічного середовища, продиктованого Четвертою промисловою революцією.

У контексті євроінтеграційних устремлінь України та потреби відповідності розвитку ії політики й економіки Копенгагенським критеріям членства в СС, ми пропонуємо дослідити місце України серед країн ЄC за показником готовності до виробництва майбутнього. Це дозволить оцінити ії конкурентоспроможність відносно країн ЄС та потенційну здатність дієво працювати в умовах глобальних трансформацій і викликів. Для цього обрано підхід, який передбачає:

- аналіз окремих компонентів інтегральної оцінки готовності до виробництва майбутнього в компаративному аспекті;

- визначення напрямів зміцнення позицій України та підвищення іiі готовності до посилення міжнародного економічного співробітництва на умовах побудови конкурентоздатності.

Управління національною економікою в умовах геоекономічних трансформацій вимагає побудови дієвої геоекономічної стратегії, яка буде заснована на максимально продуктивному використанні всіх видів ресурсів країни, проте з урахуванням глобальних тенденцій. Крім того, формувати національну економічну політику в умовах відкритості національної економіки без урахування зовнішньоекономічної кон'юнктури неможливо, а дієвість обраної стратегії та політик держави характеризується іiі конкурентоспроможністю на міжнародній економічній арені. 
«Зростаюча пов’язаність та залученість національних економік у світове господарство ставить нові виклики для підприємств та урядів і надає широкі можливості для країн посісти провідне місце у глобальній економіці, використовуючи наявний потенціал» [6, с. 88].

Підходи до оцінки ступеня розвитку країни в цілому, її бізнес-середовища чи окремої галузі через різноманітні індекси сьогодні досить широко розповсюджені. Однак переважна більшість вказаних індексів має ретроспективний характер і дозволяє оцінити стан за конкретним показником чи групою показників за результатами обмеженого проміжку часу. Водночас в умовах існування мінливого зовнішнього середовища, що характеризується невизначеністю майбутнього, значними ризиками та викликами, особливу увагу варто приділити оцінці готовності країни протистояти викликам майбутнього та адаптуватися до ймовірних ризиків. Тобто виникає потреба перспективної оцінки готовності країни до прийняття викликів у майбутньому. Крім того, в умовах Четвертої промислової революції особливо гостро постає питання вже не вміння країни адаптуватися до змін і викликів зовнішнього середовища, а швидкості такої адаптації, яка дозволить наростити чи втратити конкурентні переваги. Одним з індексів, який дає можливість оцінити готовність країни до майбутнього, є індекс готовності до виробництва майбутнього (Readiness for the Future of Production Report 2018), оприлюднений Світовим економічним форумом (WEF). На рисунках 1-2 зображено варіації показників структури виробництва та складності, а також драйверів виробництва країн ЄС і України з метою аналізу подібності показників України до інших груп (нині вона належить до незрілих країн). Розглянемо детальніше зміст та передумови наведених на рисунку показників України (для цілей цього дослідження обмежимося розглядом за складовими: складність та структура виробництва, та драйверами: людський капітал та ресурси сталого розвитку).

Структура виробництва. Про зрілість економіки свідчить структура виробництва. Вважається, що в економічно розвинених країн понад 65-70 \% ВВП створюється у сфері послуг, натомість сільське господарство має відповідну частку на рівні до 5 \%. Проте формально судити про розвиток економіки, грунтуючись виключно на структурному співвідношенні секторів економіки у ВВП, не доцільно, адже важливою є продуктивність праці у цих секторах, рівень технологічної оснащеності та складності готового продукту.

Крім того, слід брати до уваги і розвиток фінансового сектору країни, адже через фінансовий капітал здійснюється фінансування реального сектору економіки. Останній отримуватиме належну підтримку та відповідне сприятливе, передбачуване та прозоре фінансове середовище тільки у разі стабільності фінансового сектору.

У зв’язку з цим варто згадати працю Л.Дактор та Д.Гречиної, присвячену проблемам взаємозв'язків фінансового розвитку, реального сектору та економічного зростання. Дослідники наголошують на перерозподільчих зв'язках між ними. «Якщо фінансування, - пишуть вчені, - перезподіляється на ризикові інвестиції, технологічний прогрес у продуктивному секторі може розширити продуктивну здатність економіки та створює попит на основні фонди з боку більш ефективних фірм» [5, с. 2]. Погоджуємося 3 їх думкою про те, що це «стабілізує економіку, знизить ймовірність системних криз та підвищить середній рівень економічного зростання».

При цьому зауважимо, що зміна галузевої структури економік світу та його окремих регіонів $є$ однією 3 трансформацій, які мають геоекономічний характер. Ми пов'язуємо це 3 тим, що дієва реалізація геоекономічної стратегії стає можливою виключно за умов достатньо диверсифікованої структури економіки, яка здатна забезпечити адаптивність країни до нестабільних умов світових ринків товарів та послуг.

На думку С.Сардака, М.Корнєєва, А.Сімахової та О.Більської, до нинішніх глобальних тенденцій, належать «загострення конкуренції, активізація інноваційної та інвестиційної діяльності, ... поглиблення міжнародного поділу праці у сферах спеціалізації та співробітництва у виробництві» [4, с. 328]. При цьому змінювана галузева структура визначає і трансформацію попиту виробників товарів та послуг на ресурси (природні, енергетичні та трудові), а це водночас визначає перерозподіл трудових ресурсів у світі та, відповідно, їх міграційні потоки. Зауважимо також, що асиметрії у ефективності використання капіталу і його надвисока віддача у новітніх секторах економіки часто генерують дисбаланси у попиті фахівців та їх освітньо-професійному рівні, i, як наслідок, - значне структурне безробіття та «марнування мізків».

Також Л.Дактор та Д.Гречина роблять висновок щодо впливу фінансового розвитку на зниження економічного зростання у двох векторах: 1) підвищення недієздатності (крихкості) економіки; 2) нераціональне використання ресурсів. Науковці підсумували це твердження: «фінансовий розвиток може знизити економічне зростання, якщо не супроводжується розвитком у реальному секторі економіки» [5, с. 4-5]. 


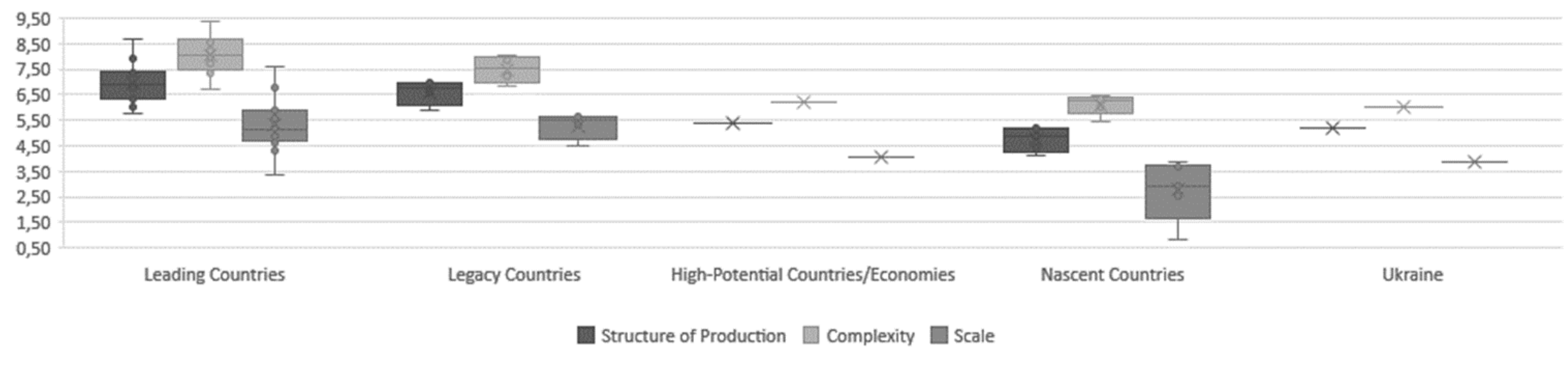

Джерело: побудовано самостійно авторами на основі Readiness for the Future of Production Report 2018) [2]

Рис. 1. Варіація показників структури виробництва та складності краӥн СС (за групами готовності крайн до майбутнього виробництва) та Украӥни у 2018 р.

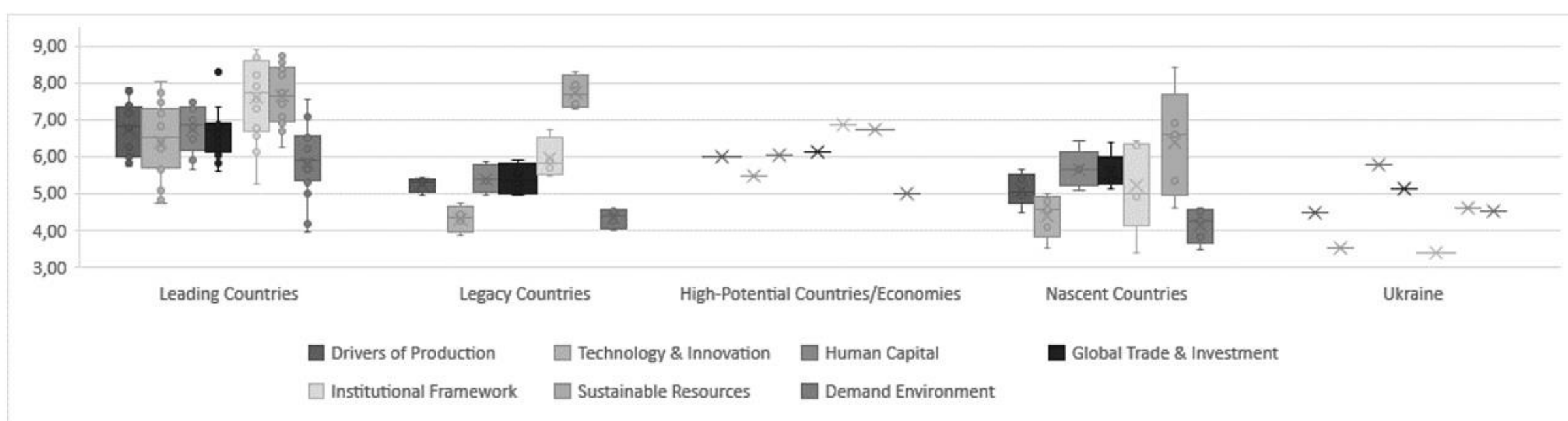

Джсерело: побудовано самостійно авторами на основі Readiness for the Future of Production Report 2018) [2]

Рис. 2. Варіація показників драйверів виробництвва крайн СС (за групами готовності краӥн до майбутнього виробництва) та Украйни у 2018 р. 
Цікавий погляд на закономірності економічних трансформацій розкрито у праці Р.Фок'є та С.Броадберрі (2015), які дослідили генезис економічного розвитку Європи протягом семи століть перед початком промислової революції. Дослідники зробили висновок, що «промислова революція не була подією, ізольованою у Великій Британії, звідки вона «походила», натомість була фазою значно тривалішого процесу економічної трансформації в Європі» [6, с. 229]. Дослідники наголошують на тому, що розуміння трансформацій, які передували бурхливому економічному розвитку на тлі Промислової революції, дають можливість проаналізувати ризики обмеженого зростання в індустріальних економіках (до речі, ця проблема характерна і для України на сучасному етапі), а також шляхи стимулювання «нової промислової промисловості».

На нашу думку, варто враховувати поточний стан ресурсного забезпечення України, та доцільні на даному етапі засоби досягнення іiї макроекономічної стабільності, інституційних реформ та модернізації механізмів управління національною економікою.

Тому для цілей нашого дослідження будемо аналізувати наведені вище компоненти та драйвери готовності до майбутнього виробництва й розглянемо їх детальніше.

Складність продукції. На показник складності впливає ціла низка економічних, історичних та інституційних передумов. Зокрема, матеріально-технічна база й виробничі потужності, як правило, розміщуються на територіях, де історично були людські, природні, енергетичні ресурси і транспортна інфраструктура. Проте досвід впровадження технологій їх використання у виробництві та удосконалення обумовлені зрілістю інституційного середовища заохочення підприємницької діяльності, розвитку інновацій, науки і техніки. Цим можна пояснити лідерство Японії, Швейцарії, Німеччини, Південної Кореї, Швеції та Сінгапуру за складністю економіки. У таблиці 1 наведено рейтинг країн ЄС, які лідирують за цим показником.

Таблиця 1

Рейтинг країн у індексі складності економіки у 2019 р.

\begin{tabular}{|c|c|c|c|c|c|}
\hline № & \multicolumn{5}{|c|}{ Індекс складності економіки (2019) } \\
\hline 4 & Німеччина & 1,923 & 12 & Словенія & 1,518 \\
\hline 7 & Чехія & 1,670 & 14 & Угорщина & 1,460 \\
\hline 8 & Швеція & 1,644 & 15 & Словаччина & 1,403 \\
\hline 9 & Австрія & 1,594 & 16 & Франція & 1,400 \\
\hline 11 & Фінляндія & 1,528 & 17 & Італія & 1,361 \\
\hline
\end{tabular}

Джерело: [11]

При цьому Україна посідає 43 місце у світі. Ми можемо пояснити це традиційною орієнтацією країни та її злочинним, зі стратегічної точки зору, позиціонуванням виключно як аграрної держави. Це по суті і визначило тривалу орієнтацію на масове сільськогосподарське виробництво низькотехнологічної продукції, яка не вимагає тривалих досліджень та розробок з відповідним фінансуванням інновацій.

Водночас саме підвищення технологічної складності продукції та ступеня її обробки, маємо на увазі в Експортній стратегії України у зв’язку з потребою забезпечення експортної експансії нашої держави. Отже, очевидно, що забезпечення максимізації кількості процедур переробки всередині країни означає зростання зайнятості, підвищення доданої вартості на продукти та, як наслідок, зростання валютних надходжень від експорту.

Людський капітал. Економіка знань формує підвищені вимоги до країн, які прагнуть брати активну участь у міжнародних економічних відносинах на конкурентних засадах, та якості людських ресурсів як носіїв і продуцентів цих знань. За даними Рейтингу недієздатності країн світу, починаючи 32013 р., зафіксовано зростання середнього показника втрати людського капіталу з 5,44 до 5,65. I хоча зростання невелике, проте кількість країн світу, де зафіксовано високий рівень недієздатності (не нижче 8 пунктів) за показником «Втрата людського потенціалу» (Е.3: Human Flight and Brain Drain), зросла вдвічі - 311 у 2012 р. до 26 у 2017 р. [13]. Це може свідчити про тенденції втрати країнами власних інтелектуальних і трудових ресурсів, що ставить подальший розвиток постіндустріальної економіки у цих країнах (або хоча б індустріальної економіки у країнах Африки) під загрозу. Щодо показників України, то варто констатувати покращення ситуації (зниження показників втрати людського капіталу з 6,3 у 2014 р. до 4,9 у 2018 р.), разом з тим, вони залишаються досить високими порівняно з країнами ЄС (лише у Литві, Латвії, Польщі та Румунії цей показник вище 4) [13].

При цьому середня оцінка загрози втрати людського капіталу у світі зростає, що означає підвищення мобільності висококваліфікованих людських ресурсів, які мігрують з країни у зв'язку з переслідуваннями або неможливістю перебування у країні.

Сардак С., Корнєєв М., Джинджоян В., Федотова Т. та Трифонова О. розглядають міграцію людських ресурсів, зазначаючи, що іiі позитивним наслідком $\epsilon$ «розширення можливості реалізації людського 
потенціалу, збагачення суспільного життя, збільшення кількості наукових досягнень та поліпшення комунікації» [7, с. 53]. Погоджуючись 3 думкою авторів, зауважимо, що контрольована міграція дійсно сприяє розвитку людського потенціалу країн та регіонів, його оптимальному використанню, $\epsilon$ каталізатором розвитку науки і техніки, що сприяє інноваційному розвитку економіки. В цілому під час формування уявлення про структуру людських ресурсів варто орієнтуватися не лише на показники гендерно-вікового складу населення, але й на загальний освітньо-професійний рівень, який потенційно визначає і структуру міграційних людських ресурсів. Серед драйверів готовності є і драйвер «людський капітал», який має низку складових, зокрема «майбутня робоча сила» (саме до цієї складової входять інші дві «міграція» і «здатність приваблювати та утримувати таланти» - вони об'єднані під загальною назвою «міграція»).

Дослідження середніх значень частки висококваліфікованої робочої сили у загальній її кількості (дані розраховано за показниками осіб з вищою освітою за 105 країнами світу за період 2009-2015 рр. на основі даних Світового банку [14] дозволило встановити, що в цілому у світі спостерігається тенденція до зменшення кількості високоосвіченого населення у загальній чисельності робочої сили ( 79,48 до 78,16 \%) в період з 2009-2015 pр. Стійку тенденцію варто виокремити за категорією країн з доходом на душу населення вище середнього (незначне зростання з 77,03 \% у 2009 р. до 77,04 \% у 2015 р.), що характеризує стабільну частку населення, яке отримує доступ до вищої освіти, що спричиняє зростання індексу людського розвитку.

Ми вважаємо за доцільне аналізувати показники людського розвитку, виходячи 3 двох основних показників та таких міркувань:

- індекс людського розвитку класично використовується для аналізу соціоекономічного становища населення, агрегує численні показники соціально-економічного розвитку;

- індекс гендерного розриву, незважаючи на значну інформаційну місткість індексу людського розвитку, варто враховувати у зв'язку з тим, що жінки є великою частиною робочої сили (звісно 3 урахуванням правових норм, переважаючих релігійних догматів та традицій різних країн та культур). I не дивлячись на те, що Україна, як правило, не демонструє значний гендерний розрив, все ж таки вона посіла у відповідному рейтингу 56 місце, а за показниками Індексу людського розвитку - 84 місце у світі (ці показники пропонуємо порівняти з показниками країн $\mathrm{CC}$, які посіли найвищі сходинки (табл. 2).

Табличя 2

Рейтинг краӥн СС за показниками людського розвитку і гендерного розриву (2020 р.)

\begin{tabular}{|c|c|c|c|c|c|}
\hline № & Індекс людського розвитку $(2020)[15]$ & № & \multicolumn{2}{|c|}{ Індекс гендерного розриву (2020) } \\
\hline 2 & Ірландія & 0,955 & 3 & Фінляндія & 0,832 \\
\hline 6 & Німеччина & 0,947 & 4 & Швеція & 0,820 \\
\hline 7 & Швеція & 0,945 & 7 & Ірландія & 0,798 \\
\hline 8 & Нідерланди & 0,944 & 8 & Іспанія & 0,795 \\
\hline 10 & Данія & 0,940 & 10 & Німеччина & 0,787 \\
\hline 11 & Фінляндія & 0,938 & 11 & Латвія & 0,785 \\
\hline 14 & Бельгія & 0,931 & 14 & Данія & 0,782 \\
\hline 18 & Австрія & 0,922 & 15 & Франція & 0,781 \\
\hline 22 & Словенія & 0,917 & 26 & Естонія & 0,751 \\
\hline 23 & Люксембург & 0,916 & 27 & Бельгія & 0,750 \\
\hline
\end{tabular}

Джерело: [16]

Дослідження людського капіталу як фактора економічного зростання проводили А.А. Техетра та А.С. Куейрос. На основі аналізу панельних даних, щодо зв'язків між людським капіталом, економічними змінами, науковці сформулювали проблему невідповідності між процесами структурних змін та ресурсами людського капіталу. Дослідники пишуть: «Для високорозвинених країн вплив людського капіталу на зростання ВВП посилюється, коли важливі галузі виробництва товарів та послуг з доданою вартістю зростають зі зростанням усієї економіки. Відсутність промислових структур, які не можуть належним чином інтегрувати високоосвічених людей до виробничої системи, спричиняє невтішні економічні наслідки для країн з перехідною економікою» [8, с. 9].

Цілком підтримуємо позицію Дж.А. Робінсона та Д.Аджемоглу щодо впливу інститутів на розвиток людського капіталу: «Інклюзивні економічні інститути створюють інклюзивні ринки, які не лише дають людям свободу пошуку професій у житті відповідно до їхніх талантів, а й забезпечують конкурентне середовище, що надає їм можливості для цього» [12, с. 70].

Ресурси сталого розвитку. Питання забезпечення сталого розвитку в процесі економічного зростання не $є$ однозначним, оскільки економічне зростання не завжди супроводжується якісним поліпшенням 
технологій та модернізацією. У цьому зв’язку заслуговує на увагу дослідження, проведене R.Jayaraman та P.F. Lanjouw. Дослідники вказують: «Фірми дрібних галузей можуть розглядатися як непропорційно великі забруднювачі в тому сенсі, що вони більше сприяють загальному забрудненню атмосфери промисловим виробництвом, ніж забезпечують промислову зайнятість» [10, с. 461]. На це твердження варто звернути увагу тому, що лібералізація умов для розвитку малого та середнього бізнесу й розширення його діяльності у сферах промисловості вимагає від країни моніторингу інтенсивності їх діяльності, впливу на навколишне середовище, а також вимог до системи екологічної безпеки та матеріальнотехнічного і сировинно-ресурсного забезпечення (це стосується не тільки дрібних фірм та галузей, проте великі компанії частіше піддаються екологічному контролю та моніторингу).

Іншим важливим питанням стратегічного характеру є структура енергоспоживання та реалізація енергетичної стратегії країни. Відповідно до результатів досліджень Bhattacharya M., Paramati S.R., Ozturk I. та Bhattacharya S. (2016), присвячених вивченню ефективності споживання відновлювальних джерел енергії на економічне зростання, Україна належить до категорії країн (разом з Індією, США та Ізраїлем), де використання відновлювальної енергії негативно впливає на економічне зростання. Зокрема, вони вказують на те, що Україна, «багата природними ресурсами є воротами російського газу у Свропу, проте відновлювані джерела становлять лише 3 \% енергоспоживання» [9, с. 740]. На нашу думку, відмова від споживання газу поставить під загрозу і його транзит, що останнім часом спостерігається у міжнародних відносинах з Росією. Не дивлячись на те, що в довгостроковій перспективі це сприятиме розвитку альтернативної енергетики, посиленню ефективності використання Україною власних ресурсів, поштовху для розвитку технологій та інновацій, проте в короткостроковому періоді означатиме втрату значної частки експорту послуг та, відповідно, валютних надходжень.

Загострення екологічних проблем у нашій державі, як і в усьому світі, потребує негайного реагування уряду та суспільства в цілому на кризові явища у системі захисту навколишнього середовища, що дозволить знизити та/або усунути негативні екологічні наслідки економічного розвитку України. Окрім цього, шлях вирішення цих проблем лежить у площині: 1) інституційних реформ у сфері охорони довкілля; 2) екологізації виробництва та побуту; 3) формування екологічної свідомості українського суспільства. Проте перший з названих напрямів на сьогодні має бути взятий за основу трансформації системи охорони навколишнього середовища, оскільки саме він $є$ правовим базисом реалізації екологічної політики України. Важливим моментом в Угоді про асоціацію України з СС є саме екологічні питання, що можна пояснити їх важливістю для цього інтеграційного об'єднання, країни якого мають значні екологічні проблеми, проте і вживають активних заходів нівелювання негативного антропогенного впливу на навколишнє середовище, що позначилося на значній розвиненості інституційного регулювання екологічних питань у ЄС. Натомість законодавство України має значні розбіжності з положеннями екологічного законодавства $\mathrm{CC}$, що зумовлює значні ризики під час здійснення експортних операцій українськими виробниками. Продемонструвати це можна через дані Індексу екологічної ефективності [18] (табл. 3).

Таблиия 3

Рейтинг країн СС за індексом екологічної ефективності у 2020 р.

\begin{tabular}{|c|c|c|c|c|c|}
\hline № & \multicolumn{5}{|c|}{ Індекс екологічної ефективності (2020) } \\
\hline 1 & Данія & 82,5 & 11 & Нідерланди & 75,3 \\
\hline 5 & Франція & 80,0 & 14 & Іспанія & 74,3 \\
\hline 6 & Австрія & 79,6 & 15 & Бельгія & 73,3 \\
\hline 7 & Фінляндія & 78,9 & 16 & Ірландія & 72,8 \\
\hline 8 & Швеція & 78,7 & 18 & Словенія & 72,0 \\
\hline 10 & Німеччина & 77,2 & 20 & Чехія & 71,0 \\
\hline
\end{tabular}

Джерело: [18]

Той факт, що Україна в цьому рейтингу посіла 60 місце, свідчить про недоліки інституційного середовища регулювання екологічності вітчизняної економіки.

Крім того, співробітництво, передбачене Угодою про асоціацію України та ЄС, здійснюється з метою збереження, захисту, поліпшення і відтворення якості навколишнього середовища, захисту громадського здоров'я, розсудливого та раціонального використання природних ресурсів та заохочення заходів на міжнародному рівні, спрямованих на вирішення регіональних і глобальних проблем навколишнього середовища. Тому саме інституційні реформи сфери охорони навколишнього середовища мають бути в основі сталого розвитку економіки нашої держави.

Варто сказати, що посилення економічної та природоохоронної ефективності функціонування промисловості завдяки сучасним технологіям є взаємопов'язаними, оскільки удосконалення виробничих процесів та модернізація виробничих потужностей, впровадження інновацій, підвищення технологічності, 
економічності та безвідходності виробництва вимагає інституційних змін на всіх рівнях господарювання, зокрема: 1) розробки національної та/або регіональної екологічної політики, яка б передбачала систему матеріального та іншого заохочення впровадження екологічних технологій на локальному рівні; 2) розробку екологічної політики компаній-забруднювачів; 3) державного сприяння впровадження концепції енергозбереження, екологізації виробництва, зниження рівня відходів та створення належної системи поводження з ними.

Висновки та перспективи подальших досліджень. Економічне зростання та висока конкурентоспроможність країни має забезпечуватися, насамперед, диверсифікованою структурою економіки. Це дозволить їй реагувати на ризики різкої негативної зміни кон'юнктури на світових ринках, знижуючи макроекономічну нестабільність, спровоковану ними. У довгостроковій перспективі це дасть змогу уникнути тривалої рецесії. Проте тривала сировинна орієнтація України та відповідна структура ії економіки визначила неможливість іiі швидкої адаптації до геополітичної кризи, потребу формування власної геоекономічної стратегії на порозі Євроінтеграційних змін.

У контексті викладеного вище перспективним напрямом подальших досліджень $є$ аналіз драйверів виробництва країн ЄС та України за іншими складовими; визначення розривів в оцінці показників України та країн СС, а також ідентифікація проблемних точок, які потребують акумуляції зусиль уряду, наукової спільноти та неурядових організацій щодо розробки стратегії та заходів ії реалізації, яка дасть можливість привести їх у відповідність до значень, рівних або наближених до значень країн-членів СС.

\section{Список використаної літератури:}

1. Stukalo N. Global parameters of social economy clustering / N.Stukalo, A.Simakhova // Problems and Perspectives in

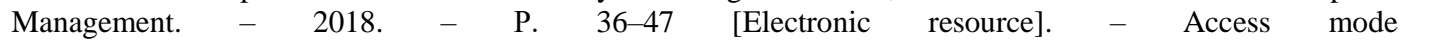
https://businessperspectives.org/journals/problems-and-perspectives-in-management/issue-276/global-parametersof-social-economy-clustering. DOI: 10.21511/ppm.16(1).2018.04.

2. Readiness for the Future of Production Report 2018 / World Economic Forum [Electronic resource]. - Access mode : http://www3.weforum.org/docs/FOP_Readiness_Report_2018.pdf.

3. Pliushchyk I.A. Hlobalizatsiini vyklyky ta mozhlyvosti dlia krain z perekhidnoiu ekonomikoiu / I.A. Pliushchyk, R.P. Ohorodnyk, N.I. Duchynska // Ekonomichni innovatsii. - 2015. - P. 88-95.

4. Global factors which influence the directions of social development / S.Sardak, M.Korneyev, A.Simakhova, O.Bilskaya // Problems and Perspectives in Management. - 2017. - № 15 (3). - P. 323-333 [Electronic resource]. Access mode : https://cutt.ly/6YnQsWc.

5. Ductor L. Financial development, real sector and economic growth / L.Ductor, D. Grechyna // International Review of Economics \& Finance. - 2015. - № 37. - P. 393-405 [Electronic resource]. - Access mode : http://eprints.mdx.ac.uk/19388/1/DuctorGrechyna_051114.pdf. DOI: 10.1016/j.iref.2015.01.001.

6. Fouquet R. Seven centuries of European economic growth and decline / R.Fouquet, S.Broadberry // Journal of Economic Perspectives. - 2015. - № 29 (4). - P. 227-244 [Electronic resource]. - Access mode : https://pubs.aeaweb.org/doi/pdf/10.1257/jep.29.4.227. DOI: 10.1257/jep.29.4.227.

7. Sardak S. Current trends in global demographic processes / S.Sardak, M.Korneyev, V.Dzhyndzhoian // Problems and Perspectives in Management. - 2018. - № 16 (1). - P. 48-57 [Electronic resource]. - Access mode : https://businessperspectives.org/journals/problems-and-perspectives-in-management/issue-276/current-trends-inglobal-demographic-processes. DOI: 10.21511/ppm.16(1).2018.05.

8. Teixeira A.A. Economic growth, human capital and structural change: A dynamic panel data analysis / A.A. Teixeira, A.S. Queirós // Research policy. - 2016. - № 45 (8). - P. 1636-1648 [Electronic resource]. - Access mode : https://cutt.ly/xYnk25U. DOI: 10.1016/j.respol.2016.04.006.

9. The effect of renewable energy consumption on economic growth: Evidence from top 38 countries / M.Bhattacharya, S.R. Paramati, I.Ozturk, S.Bhattacharya // Applied Energy. - 2016. - № 162. - P. 733-741 [Electronic resource]. Access mode : https://cutt.ly/GYnlHju. DOI: 10.1016/j.apenergy.2015.10.104.

10. Jayaraman $R$. Small-scale industry, environmental regulation, and poverty: The case of Brazil / R.Jayaraman, P.F. Lanjouw // The World Bank Economic Review. - 2004. - № 18 (3). - P. 443-464 [Electronic resource]. Access mode : https://openknowledge.worldbank.org/bitstream/handle/10986/17166/774760JRN020040Small0Scal e0Industry.pdf?sequence=1\&isAllowed=y. DOI: 10.1093/wber/lhh048.

11. Economic Complexity Rankings / Observatory of Economic Complexity. - 2016 [Electronic resource]. - Access mode : https://atlas.media.mit.edu/en/rankings/country/eci/.

12. Robinson J.A. Why nations fail: The origins of power, prosperity and poverty / J.A. Robinson, D.Acemoglu // Crown Business. - New York, 2012.

13. Fragile States Index / Fund for Peace. - 2018 [Electronic resource]. - Access mode : http://fundforpeace.org/fsi/data/.

14. Labor force with advanced education (\% of total working-age population with advanced education) / World Bank. 2017 [Electronic resource]. - Access mode : http://data.worldbank.org/indicator/SL.TLF.ADVN.ZS.

15. Human Development Data (1990-2015) [Electronic resource]. - Access mode : http://hdr.undp.org/en/data\#.

16. Global Gender Gap Index / World Economic Forum. - 2015 [Electronic resource]. - Access mode : https://www3.weforum.org/docs/WEF_GGGR_2020.pdf.

17. Про схвалення Експортної стратегії України («дорожньої карти» стратегічного розвитку торгівлі) на 2017-2021 роки / Кабінет Міністрів України [Електронний ресурс]. - Режим доступу : https://www.kmu.gov.ua/ua/npas/proshvalennya-eksportnoyi-strategiyi-ukrayini-dorozhnoyi-karti-strategichnogo-rozvitku-torgivli-na-20172021-roki. 
18. Environmental Performance Index. - Yale University, 2018 [Electronic resource]. - Access mode : https://epi.yale.edu/downloads/epi2020report20210112.pdf.

\section{References:}

1. Stukalo, N. and Simakhova, A. (2018), «Global parameters of social economy clustering», Problems and Perspectives in Management, pp. 36-47, [Online], available at: https://businessperspectives.org/journals/problemsand-perspectives-in-management/issue-276/global-parameters-of-social-economyclustering, doi: 10.21511/ppm.16(1).2018.04.

2. World Economic Forum (2018), Readiness for the Future of Production Report 2018, [Online], available at: http://www3.weforum.org/docs/FOP_Readiness_Report_2018.pdf

3. Pliushchyk, I.A., Ohorodnyk, R.P. and Duchynska, N.I. (2015), «Hlobalizatsiini vyklyky ta mozhlyvosti dlia krain z perekhidnoiu ekonomikoiu», Ekonomichni innovatsii, pp. 88-95.

4. Sardak, S., Korneyev, M., Simakhova, A. and Bilskaya, O. (2017), «Global factors which influence the directions of social development», Problems and Perspectives in Management, No. 15 (3), pp. 323-333, [Online], available at: https://cutt.ly/6YnQsWc

5. Ductor, L. and Grechyna, D. (2015), «Financial development, real sector, and economic growth», International Review of Economics \& Finance, No. 37, pp. 393-405, [Online], available at: http://eprints.mdx.ac.uk/19388/1/DuctorGrechyna_051114.pdf, doi: 10.1016/j.iref.2015.01.001.

6. Fouquet, R. and Broadberry, S. (2015), «Seven centuries of European economic growth and decline», Journal of Economic Perspectives, No. 29 (4), pp. 227-244, [Online], available at: https://pubs.aeaweb.org/doi/pdf/10.1257/jep.29.4.227, doi: 10.1257/jep.29.4.227.

7. Sardak, S., Korneyev, M. and Dzhyndzhoian, V. (2018), «Current trends in global demographic processes», Problems and Perspectives in Management, No. 16 (1), pp. 48-57, [Online], available at: https://businessperspectives.org/journals/problems-and-perspectives-in-management/issue-276/current-trends-inglobal-demographic-processes, doi: 10.21511/ppm.16(1).2018.05.

8. Teixeira, A.A. and Queirós, A.S. (2016), «Economic growth, human capital and structural change: A dynamic panel data analysis», Research policy, No. 45 (8), pp. 1636-1648, [Online], available at: https://cutt.ly/xYnk25U, doi:10.1016/j.respol.2016.04.006.

9. Bhattacharya, M., Paramati, S.R., Ozturk, I. and Bhattacharya, S. (2016), «The effect of renewable energy consumption on economic growth: Evidence from top 38 countries», Applied Energy, No. 162, pp. 733-741, [Online], available at: https://cutt.ly/GYnlHju, doi: 10.1016/j.apenergy.2015.10.104.

10. Jayaraman, R. and Lanjouw, P.F. (2004), «Small-scale industry, environmental regulation, and poverty: The case of Brazil», The World Bank Economic Review, No. 18 (3), pp. 443-464, [Online], available at: https://openknowledge.worldbank.org/bitstream/handle/10986/17166/774760JRN020040Small0Scale0Industry.pdf ?sequence $=1 \&$ isAllowed=y, doi:10.1093/wber/lhh048.

11. Observatory of Economic Complexity (2016), Economic Complexity Rankings, [Online], available at: https://atlas.media.mit.edu/en/rankings/country/eci/

12. Robinson, J.A. and Acemoglu, D. (2012), «Why nations fail: The origins of power, prosperity and poverty», Crown Business, New York.

13. Fund for Peace (2018), Fragile States Index, [Online], available at: http://fundforpeace.org/fsi/data/

14. World Bank (2017), Labor force with advanced education (\% of total working-age population with advanced education), [Online], available at: http://data.worldbank.org/indicator/SL.TLF.ADVN.ZS

15. Human Development Data (1990-2015), [Online], available at: http://hdr.undp.org/en/data\#

16. World Economic Forum (2015), Global Gender Gap Index, [Online], available at: https://www3.weforum.org/docs/WEF_GGGR_2020.pdf

17. Kabinet Ministriv Ukrai'ny (2017), Pro shvalennja Eksportnoi' strategii' Ukrai'ny («dorozhn'oi' karty» strategichnogo rozvytku torgivli) na 2017-2021 roky, [Online], available at: https://www.kmu.gov.ua/ua/npas/proshvalennya-eksportnoyi-strategiyi-ukrayini-dorozhnoyi-karti-strategichnogo-rozvitku-torgivli-na-20172021-roki

18. Yale University (2018), Environmental Performance Index, [Online], available at: https://epi.yale.edu/downloads/epi2020report20210112.pdf

Вірченко Оксана Олександрівна - магістрант кафедри цифрової економіки та міжнародних економічних відносин Державного університету «Житомирська політехніка» спеціальності 292 «Міжнародні економічні відносини», маркетолог, експертка з побудови особистого бренда та PRкомунікацій.

Наукові інтереси:

- вплив внутрішньої та зовнішньої комунікації на економічний стан компанії (бренда);

- зв'язок між етикою та об'ємом продажів;

- вплив комунікаційної стратегії на продажі компанії (бренда);

- $\quad$ вимірювання успішності бренда через призму комунікацій;

- побудова ефективної рекламної кампанії на розширення частки ринку.

E-mail: alexandraomishina@gmail.com. 
Романчук Катерина Василівна - доктор економічних наук, доцент, професор кафедри цифрової економіки та міжнародних економічних відносин Державного університету «Житомирська політехніка». https://orcid.org/0000-0002-4928-867X.

Наукові інтереси:

- міжнародні логістика та управління ланцюгами поставок;

- зовнішньоекономічна діяльність підприємства;

- організація торгівлі на світових маркетплейсах.

E-mail: kvromanchuk@gmail.com.

Шиманська Катерина Володимирівна - доктор економічних наук, завідувач кафедри цифрової економіки та міжнародних економічних відносин Державного університету «Житомирська політехніка».

https://orcid.org/0000-0003-0375-5102.

Наукові інтереси:

- міжнародна міграція людських ресурсів;

- регулювання та розвиток міжнародної торгівлі;

- цифрова трансформація економіки та бізнесу.

E-mail:kv.shymanska@gmail.com. 